\title{
Uncommon cribfellows: an infant with hypercalcemia, nephrocalcinosis, and acidosis: Questions
}

\author{
Abdulla M. Ehlayel ${ }^{1} \cdot$ Lawrence Copelovitch $^{1,2}$ (1) \\ Received: 30 October 2017 / Revised: 28 December 2017 / Accepted: 4 January 2018 / Published online: 19 February 2018 \\ (C) IPNA 2018
}

Keywords Hypercalcemia $\cdot$ Distal renal tubular acidosis $\cdot$ Nephrocalcinosis

\section{Case}

A 2-week-old girl presented with emesis and failure to thrive. She was treated with ranitidine and lansoprazole for presumed gastroesophageal reflux. Her birth weight was $3.5 \mathrm{~kg}$ (70th percentile). Physical exam was notable for a weight of $3.42 \mathrm{~kg}$ (30th percentile) but was otherwise unremarkable. Laboratory studies at 5 weeks of age revealed a serum sodium level of 136 (normal 133-140) $\mathrm{mmol} / \mathrm{L}$, potassium level of 4.1 (normal 4.1-5.8) $\mathrm{mmol} / \mathrm{L}$, chloride level of 105 (normal 96-106) $\mathrm{mmol} / \mathrm{L}$, carbon dioxide concentration of 18 (normal 20-26) $\mathrm{mmol} / \mathrm{L}$, creatinine level of $0.2 \mathrm{mg} / \mathrm{dL}$ and calcium level of 11.7 (normal 9.310.7) $\mathrm{mg} / \mathrm{dL}$. Over the next 2 months she had persistent emesis and poor weight gain. Serial evaluation of her electrolytes over that time perod demonstrated serum calcium and bicarbonate levels which ranged from 11.2 to $11.7 \mathrm{mg} / \mathrm{dL}$ and from 17 to $20 \mathrm{mmol} / \mathrm{L}$, respectively. Urinalysis showed a specific gravity of $1.001, \mathrm{pH}$ of 7.5 and no blood or protein.

At 4 months of age her weight was $4.8 \mathrm{~kg}$ ( $<3$ rd percentile). Further evaluation of the hypercalcemia and acidosis revealed a phosphorus level of 6.0 (normal 4.8-8.2) $\mathrm{mg} /$

The answers to these questions can be found at https://oi.org/10.1007/ s00467-017-3912-8.

Lawrence Copelovitch

Copelovitch@email.chop.edu

1 Division of Nephrology, Department of Pediatrics, The Children's Hospital of Philadelphia, 34th Street and Civic Center Boulevard, Philadelphia, PA 19104-4339, USA

2 Perelman School of Medicine, University of Pennsylvania, Philadelphia, PA, USA
$\mathrm{dL}$, magnesium level of 2.0 (normal range 1.5-2.5) $\mathrm{mg} / \mathrm{dL}$, an intact parathyroid hormone level of $<3.4$ (normal range 9 56) $\mathrm{pg} / \mathrm{mL}$, a 25-hydroxyvitamin D level of 38.2 (sufficient 30-80) $\mathrm{ng} / \mathrm{mL}$ and a 1,25 hydroxy vtamin D level of 29.1 (normal range 19.9-79.3) pg/mL. The urine calcium to creatinine ratio was 0.8 , and the urine anion gap $\left(\mathrm{Na}^{+}+\mathrm{K}^{+}-\mathrm{Cl}^{-}\right)$ was $+16.7 \mathrm{mmol} / \mathrm{L}$. Renal ultrasound demonstrated normalsized kidneys (length: right $5.5 \mathrm{~cm}$, left $5.3 \mathrm{~cm}$ ) with bilateral medullary nephrocalcinosis. At this time, potassium citrate therapy was initiated, and the dose was titrated to a final dose of $3.5 \mathrm{mEq} / \mathrm{kg}$ body weight/day over the next year. The gastrointestinal symptoms significantly improved and she had appropriate weight gain. Notably the serum calcium levels dramatically improved after the initiation of potassium citrate therapy, ranging from 9.7 to $10.9 \mathrm{mg} / \mathrm{dL}$. At 15 months of age, her weight was $9.8 \mathrm{~kg}$ (50th percentile), serum bicarbonate level was $19 \mathrm{mmol} / \mathrm{L}$ and her serum calcium was $10.5 \mathrm{mg} / \mathrm{dL}$.

\section{Questions}

1. What is the differential diagnosis for nephrocalcinosis in infancy?

2. Which of these conditions are associated with hypercalcemia?

3. Which of these diagnoses are associated with acidosis?

\section{Compliance with ethical standards}

Financial disclosure This manuscript did not receive any specific grant from funding agencies in the public, private, commercial, or not-for profit sectors.

Conflict of interest The authors have no conflicts of interest to disclose. 